\title{
Biocontrol activity of Bacillus against a GFP-marked Pseudomonas syringae pv. tomato on tomato phylloplane
}

\author{
R. Lanna Filho • R. M. de Souza • A. Ferreira • \\ M. C. Quecine • Eduardo Alves • J. L. de Azevedo
}

Received: 4 October 2011 / Accepted: 6 May 2013 / Published online: 20 June 2013

(C) Australasian Plant Pathology Society Inc. 2013

\begin{abstract}
We report the biocontrol activity of the endophytic bacteria Bacillus pumilus and Bacillus amyloliquefacies against the plant pathogenic bacterium Pseudomonas syringae pv. tomato strain NS4 transformed with the GFP expressing gene. P. s. pv. tomato strain NS4 was obtained from the transformation of $P$. s. pv. tomato wild-type strain NW with the plasmid pNKGFP containing GFP-cassette for chromosomal integration. The GFP-marked strain was tested for hypersensitivity and pathogenicity, as well as population studies on the phylloplane, to determine its epidemiology and survival. In all of the bioassays strain NS4 presented similar characteristics to the wild-type, and was hence chosen as the model strain for these studies with antagonistic endophytic bacterial strains. In the biocontrol experiments, tomato plants were preinoculated with the endophytic bacteria 4 days prior to inoculation with P. s. pv. tomato strains. On the tomato phylloplane the P. $s$. pv. tomato (strains NW and NS4) populations were drastically reduced, and tomato leaves showed reduced numbers of bacterial speck lesions, comparable to the standard chemical treatment copper oxychloride. Additionally, under epifluorescence microscopy, few GFP-tagged cells of strain NS4 were observed colonizing important niches on the tomato
\end{abstract}

R. Lanna Filho $(\bowtie)$

Phytossanity Department, Federal University of Rio Grande do Sul, 91540-000 Porto Alegre, RS, Brazil

e-mail: lanna.filho@ufrgs.br

R. M. de Souza $\cdot$ E. Alves

Plant Pathology Department, Federal University of Lavras,

37200-000 Lavras, MG, Brazil

\section{A. Ferreira}

Brazilian Agricultural Research Corporation-Embrapa

Agrosilvopastoral, 78550-970 Sinop, MS, Brazil

M. C. Quecine ·J. L. de Azevedo

Genetics Department, Federal University of São Paulo, Escola Superior de Agricultura 'Luiz de Queiroz', 13418-900 Piracicaba, SP, Brazil phylloplane. However, leaves untreated with the antagonists presented a large number of GFP-tagged cell aggregates. Our results demonstrated that endophytic bacteria can also act efficiently on the biocontrol of bacterial speck when applied as a foliar spray on the leaves. In addition, we highlighted the use of GFP-marked strain NS4 as a model system to study biocontrol agent and pathogen interactions, and growth and development of the pathogen on the tomato leaf surface.

Keywords Bacterial speck · Biological control · Endophytic bacteria $\cdot$ Bacillus pumilus $\cdot$ Bacillus amyloliquefaciens . Green fluorescent protein

\section{Introduction}

Pseudomonas syringae pv. tomato (ex Okabe) Young, Dye and Wilkie is a Gram-negative bacterium that causes bacterial speck disease on tomato leaves (Solanum lycopersicum L.) and necrosis of stems and fruits (Jones et al. 1991). Bacterial infection in young tomato plants may result in up to $75 \%$ yield loss, compared to only $5 \%$ when infection occurs in older plants (Yunis et al. 1980). P. syringae pv. tomato has been found growing epiphytically on plant foliage without causing disease symptoms (Hirano and Upper 2000). Due to its importance it has been the target of numerous studies to understand the molecular mechanisms and co-evolution of pathogenesis and plant disease resistance (Shen and Keen 1993; Melotto et al. 2006).

Control of bacterial speck is usually accomplished by copper-based pesticides as well as mancozeb, zineb, and some antibiotics (Jardine and Stephens 1987; Saad and Hassan 2000). However, when environmental conditions favor disease development and inoculum levels are high, standard treatments are not always effective (Jardine and Stephens 1987). Biocontrol, therefore, may offer an ecologically viable alternative for the management of bacterial 
speck, potentially reducing the use of conventional pesticides. Currently, several researchers have demonstrated the biocontrol potential of the genus Bacillus, acting as phyllobacteria, rhizobacteria and endophytic bacteria (Silva et al. 2004; Halfeld-Vieira et al. 2006; Campos Silva et al. 2008; Lanna Filho et al. 2010). In the case of endophytic bacteria, numerous reports have shown that these microorganisms are also capable of inhabiting other environments, such as the phyllosphere and rhizosphere (Compant et al. 2005). This demonstrates that these microorganisms are versatile and readily able to adapt to different plant environments, expanding their possible uses in economically important crops.

In this context, here we report the transformation of $P$. syringae pv. tomato wild-type strain NW with the pNKGFP plasmid containing GFP-cassettes by chromosomal integration and expression of the GFP gene. In addition, strains of $P$. syringae pv. tomato expressing the GFP gene were subjected to population, hypersensitivity and pathogenicity studies on the tomato phylloplane. We also describe the antagonistic effect of the endophytic bacterial strains $B$. pumilus Meyer and Gottheil and B. amyloliquefaciens (ex Fukumoto) Priest et al. (1987) and their effectiveness as biocontrol agents against GFP transformed P. syringae pv. tomato strains NW, NS1, NS2, NS3 and NS4.

\section{Materials and methods}

Microorganisms, plants and growth conditions

The P. syringae pv. tomato wild-type strain NW was obtained from the collection at the Bacteriology Laboratory of the Plant Pathology Department, Federal University of Lavras. The integrative plasmid pNKGFP (Ferreira et al. 2008), which contains the Green Fluorescent Protein $(G F P)$ gene in a mini- $\mathrm{Tn} 10$ derivative with a kanamycin $(\mathrm{kn})$ resistance gene was maintained in Escherichia coli DH5a pir. The endophytic bacteria Bacillus amyloliquefaciens and Bacillus pumilus, previously isolated from tomato stem, were selected for this study because they had previously shown good biocontrol activity against $P$. syringae pv. tomato (Campos Silva et al. 2008). All bacterial isolates were maintained on 523 medium (Kado and Heskett 1970) and preserved at $-80{ }^{\circ} \mathrm{C}$ in $30 \%$ (v/v) glycerol (Gerhardt 1994).

All in vivo experiments were conducted at the Laboratory of Plant Bacteriology, Department of Plant Pathology of the Federal University of Lavras, Minas Gerais State, Brazil. Tomato plants cultivar Santa Cruz 'Kada' were selected for these experiments and grown in a non-sterilized mixture of soil, sand and cattle manure $(2: 1: 1, \mathrm{v} / \mathrm{v} / \mathrm{v})$ containing $4 \mathrm{~g} / \mathrm{L}$ of NPK (4:14:8) in a greenhouse at $28{ }^{\circ} \mathrm{C} \pm 4{ }^{\circ} \mathrm{C}$ and relative humidity of $70 \%$.
P. syringae pv. tomato strain NW transformation

P. syringae pv. tomato strain NW was initially grown for $18 \mathrm{~h}$ at $28^{\circ} \mathrm{C}$ in $5 \mathrm{~mL}$ SOB liquid medium (Sambrook et al. 1989). This starter culture was then added to $250 \mathrm{~mL} \mathrm{SOB}$ liquid medium and incubated at $28{ }^{\circ} \mathrm{C}$ under continuous shaking for $12 \mathrm{~h}$ (Final cell density was $\mathrm{DO}_{600}=7.0$ ). The cells were harvested by centrifugation $(3,000 \times g ; 10 \mathrm{~min}$; $4{ }^{\circ} \mathrm{C}$ ), re-suspended in $250 \mathrm{~mL}$ of cold ultrapure water and centrifuged. The supernatant was discarded and the bacterial pellet re-suspended in $10 \%$ glycerol and centrifuged. Transformation was performed by electroporation (Gene Pulser, BioRad-2.5 kV, $25 \mu \mathrm{F}, 200 \Omega$ ) in an electroporation curvette $(0.2 \mathrm{~cm})$ containing a mixture of $100 \mu \mathrm{L}$ of cell suspension plus $1 \mu \mathrm{g}$ of pNKGFP plasmid. After transformation, $1 \mathrm{~mL}$ of Luria-Bertani (LB) medium was added, the mixture incubated for $1 \mathrm{~h}$ at $28^{\circ} \mathrm{C}$ and plated on LB medium supplemented with kanamycin $(50 \mathrm{mg} / \mathrm{mL})$. The identification and selection of clones carrying the GFP gene was carried out under UV light.

Hypersensitivity and pathogenicity assays

Hypersensitivity was tested on soybean (Glycine max) and tobacco (Nicotiana benthamiana) plants. Plants were inoculated with four GFP-marked P. s. pv. tomato strains (NS1, NS2, NS3 and NS4) and the wild-type strain NW (20 $\mu \mathrm{L}$; $\mathrm{OD}_{540}=0.2$; suspension cells $\sim 10^{8} \mathrm{cfu} / \mathrm{mL}$ ) by infiltration into the abaxial side of intact leaves with a plastic syringe (without a needle) and the inoculation points identified by ink marks on the upper leaf surface. Water was used as a control.

Fifteen day old tomato seedlings, cultivated in polyethylene pots with $500 \mathrm{~mL}$ of non-sterilized mixture of soil, sand and cattle manure $(2: 1: 1, \mathrm{v} / \mathrm{v} / \mathrm{v})$ containing $4 \mathrm{~g} / \mathrm{L}$ of NPK (4:14:8), were used for the pathogenicity studies. Plants were inoculated $(15 \mathrm{~mL}$ per plant $)$ by spray (Devilbiss EGA-502) with suspensions of GFP-marked P. s. pv. tomato strains (NS1, NS2, NS3 and NS4) and the wild-type $\mathrm{NW}\left(\mathrm{OD}_{540}=0.2\right.$; suspension cells $\left.\sim 10^{8} \mathrm{cfu} / \mathrm{mL}\right)$. Inoculated plants were maintained in a greenhouse at $28^{\circ} \mathrm{C}$ and the number lesions counted once disease symptoms had fully developed. For each treatment, four replicates were used, with one plant per pot considered as one replicate. Each experiment was conducted three times.

Bacterial population dynamics on the phylloplane

Fifteen day old tomato seedlings were inoculated $(15 \mathrm{~mL}$ per pot) by spray (Devilbiss EGA-502) with suspensions of the GFP-marked P. s. pv. tomato strains (NS1, NS2, NS3 and NS4) and the wild-type NW $\left(\mathrm{OD}_{540}=0.2\right.$; suspension cells $\sim 10^{8} \mathrm{cfu} / \mathrm{mL}$ ). Eight leaflets were collected randomly in the upper, middle and lower third of each tomato plants 
and placed in flasks containing $100 \mathrm{~mL}$ of sterile phosphate buffer (PBS) (0.1 M; pH 7.0; containing $0.05 \%$ Tween-80) and sonicated for $8 \mathrm{~min}$ in an ultrasonic cleaning bath to recover bacterial cells. Bacterial populations were estimated from $3 \mathrm{~g}$ of healthy leaflets $(=8$ leaflets total) randomly sampled from each plant pot. Serial dilutions (factor $=$ $1: 10^{3}$ ) of leaf washings were plated on 523 semi-selective medium containing cycloheximide $(50 \mu \mathrm{g} / \mathrm{mL})$ and cephalexin $(50 \mu \mathrm{g} / \mathrm{mL})$. The wild-type strain $\mathrm{NW}$ and the four GFP-marked $P$. $s$. pv. tomato bacteria were constitutively resistant to the cephalexin.

In parallel, B. pumilus and B. amyloliquefacies endophytic bacteria were sprayed $\left(\mathrm{OD}_{540}=0.2\right.$; suspension cells $\sim 10^{8} \mathrm{cfu} / \mathrm{mL}$ ) on tomato the plants. Eight leaflets were collected randomly in the upper, middle and lower third from seedlings grown in a greenhouse and placed in flasks containing $100 \mathrm{~mL}$ of sterile phosphate buffer $(0.1 \mathrm{M}$; $\mathrm{pH} 7.0$; containing $0.05 \%$ Tween-80) and sonicated for $8 \mathrm{~min}$ in an ultrasonic cleaning bath to recover bacterial cells. Bacterial populations were estimated from $3 \mathrm{~g}$ of symptomless leaflets ( $=8$ leaflets total) randomly sampled from each plant pot. Appropriate dilutions of leaf washings were plated on 523 medium containing cycloheximide $(50 \mu \mathrm{g} / \mathrm{mL})$ and neomycin $(50 \mu \mathrm{g} / \mathrm{mL})$. The B. pumilus and $B$. amyloliquefaciens endophytic bacteria were neomycin resistant.

Inoculated tomato leaves were collected at $24 \mathrm{~h}$ intervals over a 10 days period and population sizes were estimated from plate counts made after 2 to 3 days' incubation at $28{ }^{\circ} \mathrm{C}$. For each treatment, four replicates were used, with $3 \mathrm{~g}$ of leaflets ( $=8$ leaflets total) per pot considered as one replicate.

\section{Phylloplane biocontrol}

Fifteen day old tomato seedlings were sprayed as previously described with a suspension $\left(\mathrm{OD}_{540}=0.2\right.$; suspension cells $\sim 10^{8} \mathrm{cfu} / \mathrm{mL}$ ) of live cells of $B$. pumilus and $B$. amyloliquefaciens. Four days later, plants were inoculated with $P$. s. pv. tomato strain NW and NS4 $\left(\mathrm{OD}_{540}=0.2\right.$; suspension cells $\sim 10^{8} \mathrm{cfu} / \mathrm{mL}$ ). Leaves were collected and bacterial cell recovered and populations estimated as described above. For each treatment, four replicates were used, with $3 \mathrm{~g}$ of leaflets ( $=8$ leaflets total) per pot considered as one replicate.

\section{Control of bacterial speck}

Fifteen day old tomato seedlings were sprayed as previously described with a suspension $\left(\mathrm{OD}_{540}=0.2\right.$; suspension cells $\left.\sim 10^{8} \mathrm{cfu} / \mathrm{mL}\right)$ of live cells of $B$. pumilus and $B$. amyloliquefaciens, copper oxychloride (CO) (2 g/L) (positive control) and water (negative control). Four days later, plants were inoculated with $P$. $s$. pv. tomato strain NW and NS4 $\left(\mathrm{OD}_{540}=0.2\right.$; suspension cells $\left.\sim 10^{8} \mathrm{cfu} / \mathrm{mL}\right)$. Inoculated plants were kept in the greenhouse, and after disease symptoms had fully developed, the number of lesions per leaf counted on all leaflets. Each experiment was repeated three times for each pathogen with ten replicates per trial, each consisting of one plant.

\section{Fluorescence microscopy}

Ten day old tomato plants were sprayed with a suspension of live cells of B. pumilus and B. amyloliquefaciensin water. Four days later, plants were inoculated with P. s. pv. tomato strain NS4. After 5 days, $1 \mathrm{~cm}$ diameter leaflet discs were removed and placed on a glass microscope slide in $30 \%$ $(\mathrm{v} / \mathrm{v})$ glycerol. Fluorescence microscopy was conducted with an Axio Observer Z1 microscope (Carl Zeiss Microimaging GmbH, Göttingen, Germany), and the images taken using an AxioVision 4.6 Image Program, Zeiss. GFP-tagged bacterial cells were excited with UV light using a $488 \mathrm{~nm}$ filter.

\section{Scanning electron microscopy (SEM)}

Ten day old tomato plants were sprayed as previously described with a suspension of live cells of $B$. pumilus and $B$. amyloliquefaciens and water. After 4 days, three leaves per treatment were cut, and fixed using a modified Karnovsky solution (glutaraldehyde $2.5 \%$ and paraformaldehyde $2.5 \%$ in sodium cacodylate buffer $0.05 \mathrm{~mol} / \mathrm{L}$; $\mathrm{pH} 7.2$; $\mathrm{CaCl}_{2} 0.001 \mathrm{~mol} / \mathrm{L}$ ), for $24 \mathrm{~h}$ at $4{ }^{\circ} \mathrm{C}$, infiltrated with a cryoprotection solution (glycerol $30 \%$ in water) for 30 min, and cross-sectioned with a scalpel blade after being immersed in liquid nitrogen. The sections obtained were transferred to a $1 \%$ aqueous solution of osmium tetroxide for $1 \mathrm{~h}$ at room temperature, and subsequently dehydrated for $10 \mathrm{~min}$ each in a graded series of acetone solutions (25, 50, 75, 90 and $100 \%$ ). They were then dried in a Balzers CPD 030 critical point dryer (Balzers, Liechtenstein, Germany). The specimens obtained were mounted on aluminum stubs with double-stick carbon tape on aluminum foil, with the sectioned side in liquid nitrogen up, sputtercoated with gold in a Balzers SCD 050 sputter (Balzers, Liechtenstein, Germany) and observed with a scanning electron microscope (SEM) LEO EVO 40 XVP (Leo Electron Microscopy, Cambridge, UK). Leaves of healthy tomato plants exposed to PBS were used as controls. Two images were generated and three leaflets were used for each treatment. Images of the phylloplane region were generated randomly for each sample, at several magnifications, and digitally recorded. Images were processed using the software Corel Draw 12, with which comparisons among treatments were made. 


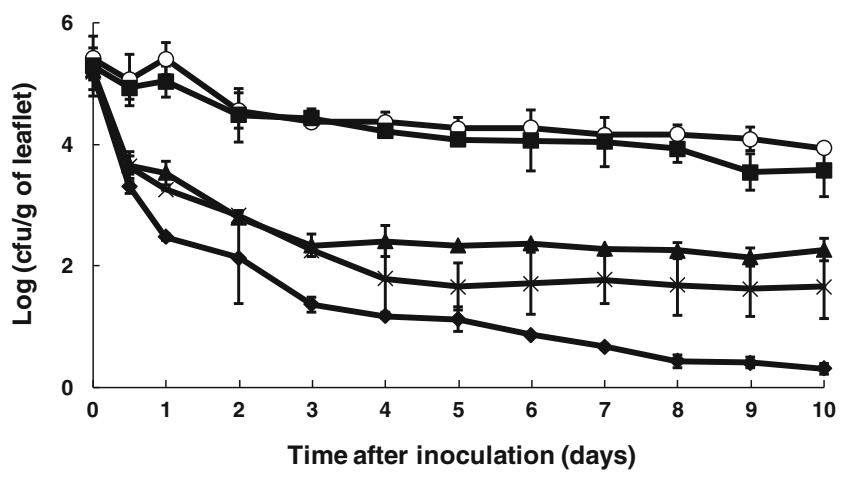

Fig. 1 Epiphytic populations over time of P. syringae pv. tomato strains on tomato inoculated by spraying $\left(\mathrm{OD}_{540}=0.2\right.$; suspension

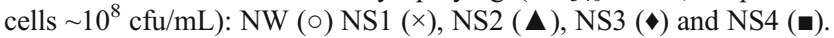
Each point represents the mean \pm standard error of the mean of four replicates

\section{Statistical analysis}

The layout for all experiments were arranged out in a completely randomized design (CRD) under plastic-greenhouse conditions, with the number of treatments and repetitions varied according to each experiment described above. The results were subjected to Analysis of Variance (ANOVA) and means compared by Tukey test $(p \leq 0.05)$ using the software Statistica ${ }^{\circledR}$, version 7.0 (Statsoft 2005).

\section{Results}

Electroporation and pathogenicity testing

The transformation of P. s. pv. tomato wild-type strain NW by pNKGFP plasmid containing GFP-cassettes for chromosomal integration and expression of GFP gene, generated four GFPmarked bacteria that under fluorescence microscopy expressed

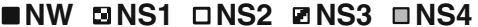

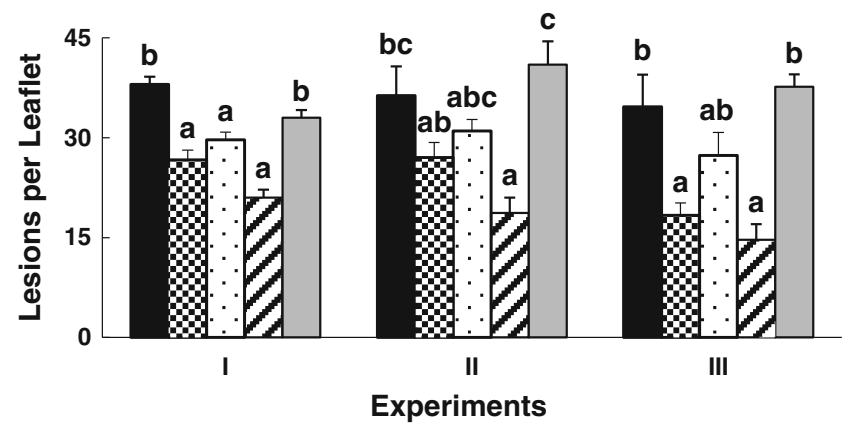

Fig. 3 Severity of P. s. pv. tomato GFP-marked strains and NW (control) artificially inoculated on Santa Cruz 'Kada' tomato plants. The experiments were repeated three times (I, II and III) for each strain (NW, NS1, NS2, NS3 and NS4). Each treatment was run with four repetitions and each repetition consisted of one plant per pot. The columns represent the mean and vertical bars represent the standard error of the mean. Means followed by same letter do not differ by the Tukey test $(p \leq 0.05)$

the GFP gene. Population behavior of the GFP-marked strains NS1, NS2, NS3 and NS4 was tested on the tomato phylloplane and, of these, strain NS4 presented population dynamics similar to that of the wild-type over the 10 days of monitoring (Fig. 1). In addition, at 10 days the population of the NW and NS4 strains on the phylloplane remained at elevated levels with $3.9 \times 10^{6}$ and $3.5 \times 10^{6}$ (cfu/g of leaves), respectively. The hypersensitivity test was positive for all the tested GFPmarked strains, showing a hypersensitive response (HR) in soybean and tobacco leaves, inducing necrotic lesions after $24 \mathrm{~h}$ of infiltration of the bacterial suspensions (Fig. 2). In the pathogenicity test on tomato leaves all the GFP-marked strains caused disease symptoms. Strain NS4 exhibited the highest disease severity levels, compared with the control (NW) (Fig. 3) and was subsequently chosen as the challenger pathogen against the endophytic bacteria $B$. amyloliquefaciens and $B$. pumilus for the biocontrol assays.
Fig. 2 Photography, tobacco (a) and soy leaves (b) showing hypersensitive response to $P$. $s$. pv. tomato GFP-marked strains. The leaves were infiltrated with the 1 = water (control),

$2=$ strain NS1, $3=$ strain NS2, $4=$ strain NS3, $5=$ strain NS4 and $6=$ strain NW and photographed after $48 \mathrm{~h}$. The bacterial cell suspensions were infiltrated at a concentration of $1.0 \times 10^{8} \mathrm{cfu} / \mathrm{mL}$. (Bars $\left.=2 \mathrm{~cm}\right)$
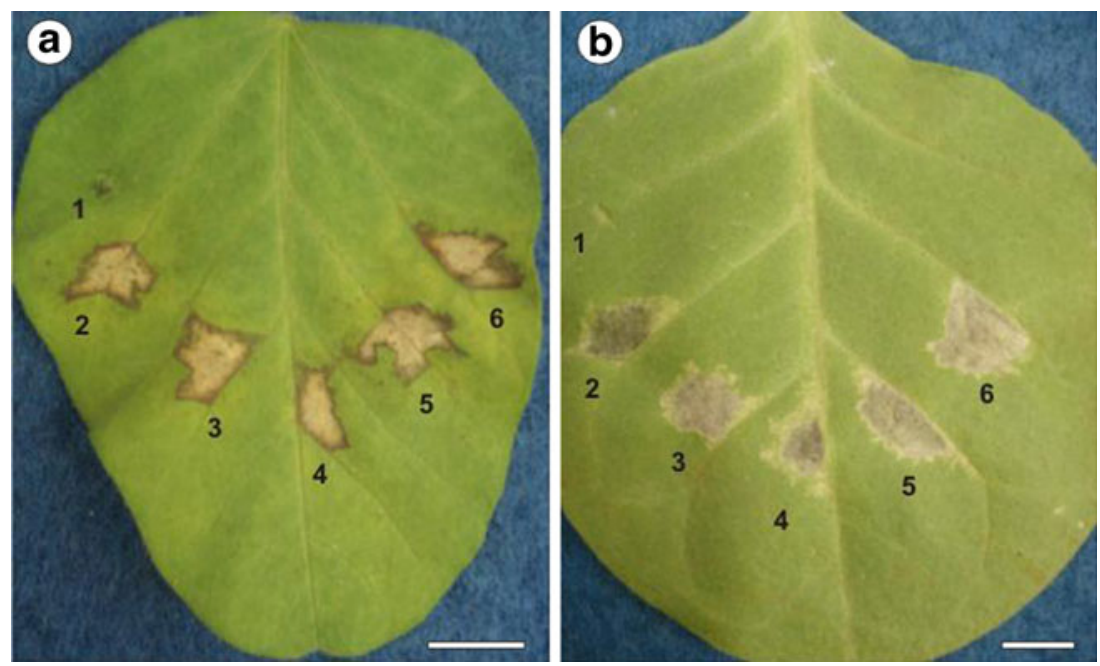


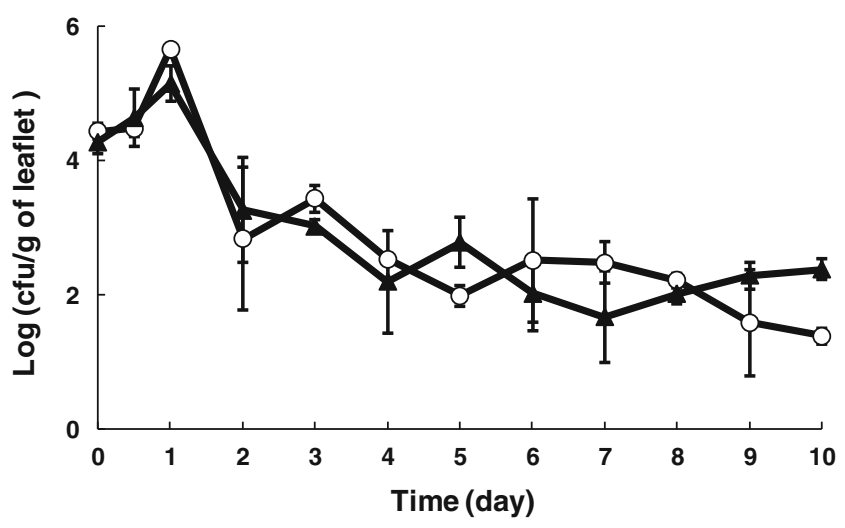

Fig. 4 Endophytic bacterial populations over time of B. pumilus (O) and B. amyloliquefaciens $(\boldsymbol{\Delta})$ sprayed on tomato leaves. Each data point indicates the mean of the log (cfu/g of leaflet) bacterial population. Each point represents the mean \pm standard error of the mean

\section{Phylloplane biocontrol}

The biocontrol agents $B$. pumilus and B. amyloliquefaciens were able to survive on the tomato phylloplane for at least 10 days resulting in population levels of $1.3 \times 10^{6}$ and $2.3 \times$ $10^{6}$ (cfu/g of leaves), respectively (Fig. 4). In addition, tomato leaves sprayed with the endophytic bacteria and, 4 days later, inoculated with NS4 and NW, and assessed after 10 days resulted in lower $P$. s. pv. tomato population levels (Fig. 5), compared to unsprayed leaves. Leaves pretreated with $B$. pumilus reduced $P$. s. pv. tomato leaf populations of NW and NS4 by 75 and $84 \%$, respectively. However, leaves pre-treated with $B$. amyloliquefaciens reduced populations of NW and NS4 by 90 and $97 \%$, respectively. In addition, plants sprayed with the antagonists, and inoculated with $P$. s. pv. tomato 4 days later, developed lower bacterial speck severity than the copper oxychloride treatment (positive control). The highest disease severity

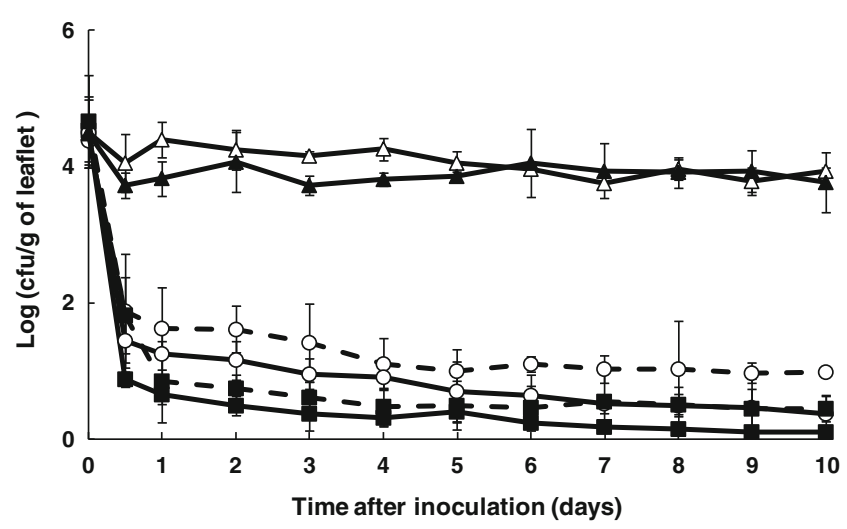

Fig. 5 Epiphytic populations over time of NW (०) and NS4 ( $\square)$ on tomato leaves 4 days after exposure to treatments with B. pumilus (- $)$ and $B$. amyloliquefaciens $(-)$. For control, tomato leaves were sprayed with water and after 4 days inoculated with NW $(\Delta)$ and NS4 $(\boldsymbol{\Delta})$. Each data point indicates the mean of the log-transformed bacterial population. Each point represents the mean \pm standard error of the mean
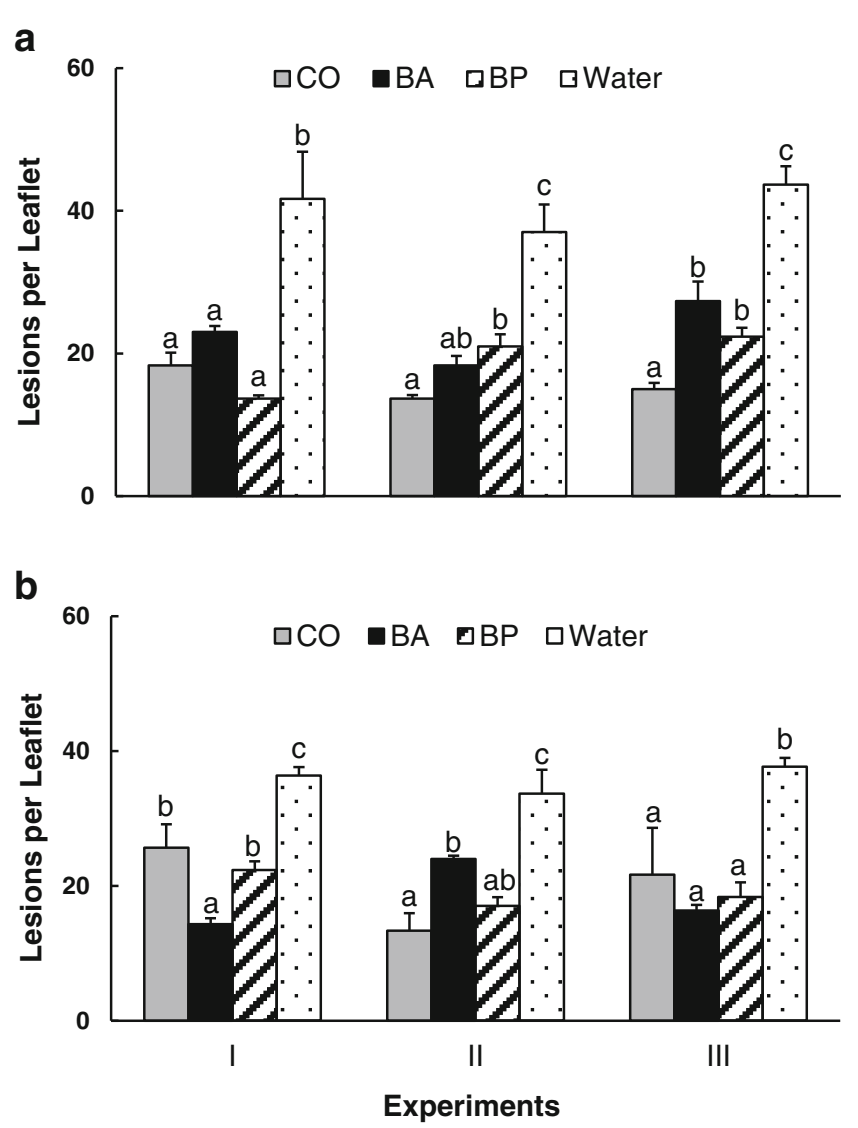

Fig. 6 Severity of bacterial speck caused by P. s. pv. tomato wild-type strain NW (a) and strain NS4 (b), artificially inoculated on Santa Cruz 'Kada' tomato plants, 4 days after exposure to treatments: copper oxichloride (CO), B. amyloliquefaciens (BA), B. pumilus (BP), and water (negative control). The experiments were repeated three times (I, II and III) for each pathogen; each treatment was run with ten repetitions and each repetition consisted of one plant per pot. Means followed by same letter do not differ by the Tukey test $(p \leq 0.05)$. The columns represent the mean and vertical bars represent the standard error of the mean

levels occurred in plants sprayed with water (negative control) (Fig. 6).

Fluorescence and scanning electron microscopy

The studies under epifluorescence microscopy showed that on the tomato phylloplane treated with the endophytic bacteria, the GFP-tagged cells of $P$. $s$. pv. tomato strain NS4 were found in small isolated but important niches, such as at the trichome base and between the depressions along the junctions of adjacent epithelial cells (Fig. 7). However, when the phylloplane was not treated with antagonists, $P$. $s$. pv. tomato was found in high numbers, efficiently colonizing the foliar surface and forming large clusters at the trichome base and between the depressions along the junctions of adjacent epithelial cells (Fig. 7f). The pattern of colonization by the epiphytic bacteria on the phylloplane showed they established themselves in cell aggregates at 
Fig. 7 Photomicrographs under epifluorescence microscope of living cells of $P$. s. pv. tomato strain NS4 expressing the GFP, on tomato leaf surfaces. Single bacterial cell at trichome base (a) and between the depressions along the junctions of adjacent epithelial cells (b) on leaf sprayed with $B$.

amyloliquefaciens; single bacterial cells at trichome base (c) and between the depressions along the junctions of adjacent epithelial cells (d) of leaf sprayed with $B$. pumilus; large bacterial cluster formation at trichome base (e) and between the depressions along the junctions of adjacent epithelial cells (f), on tomato leaf surface not sprayed with endophytic bacteria. $($ Bars $=20 \mu \mathrm{m})$
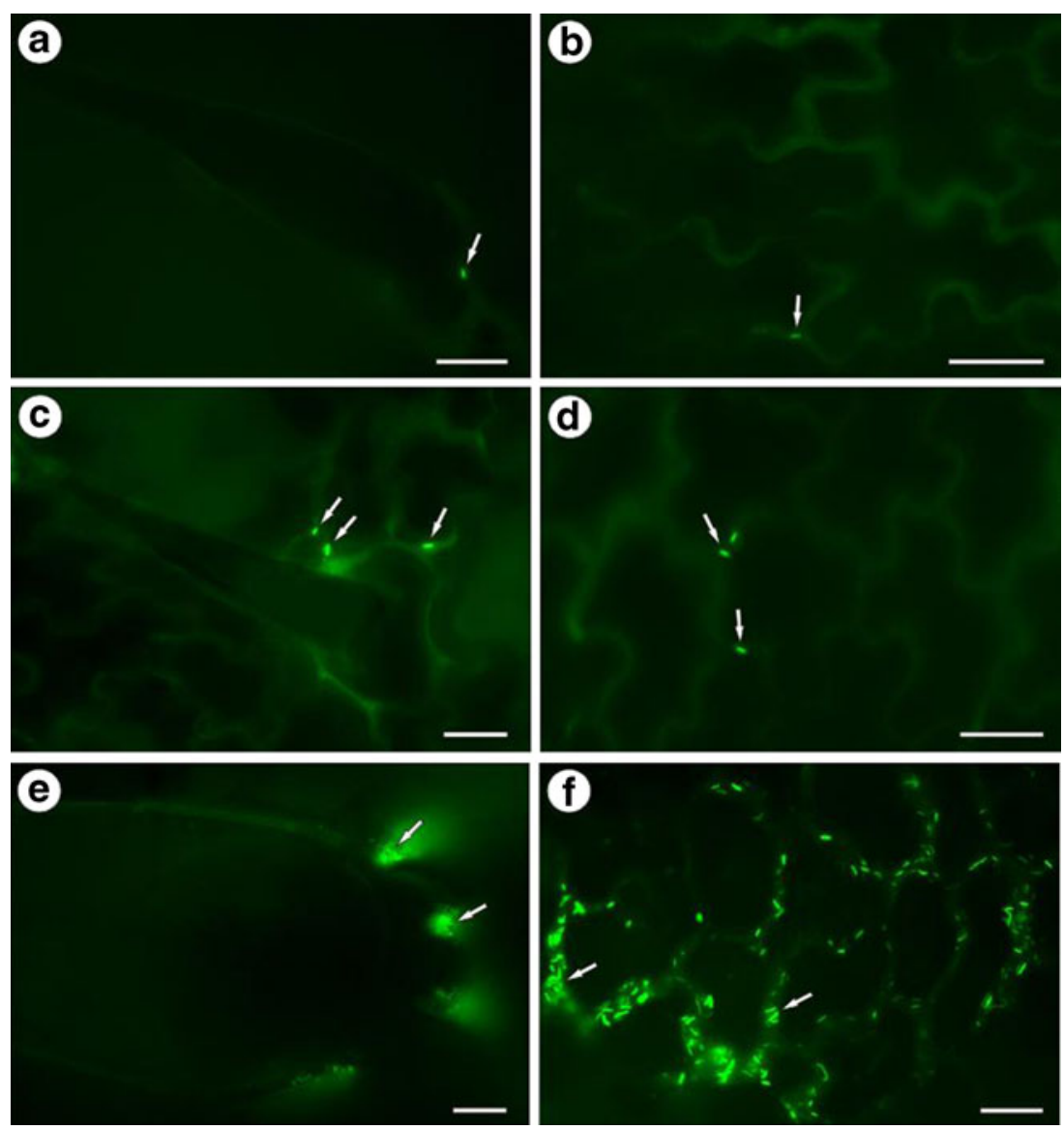

specific sites on the foliar surface (Fig. 8). These were, in the depressions along the junctions of adjacent epithelial cells (Fig. 8a and b) and beside the stomatal region (Fig. $8 \mathrm{~b}$ and c). As expected, the treatment with water did not present bacterial colonization (Fig. 8e and f).

\section{Discussion}

Transformation of $P$. s. pv. tomato by electroporation using the plasmid pNKGFP produced four GFP-marked strains which showed a satisfactory GFP expression. However, other factors should be considered as instance the effects of GFP expression on the metabolism and survival of target organism, being very important studies about the mutant growth behavior (Ma et al. 2011). Some studies have reported a non-effect on the behavior of GFP-target bacteria (Skillman et al. 1998; Allison and Sattenstall 2007). However, other researchers have been described that GFP affects the bacterial growth (Bloemberg et al. 1997; Dandie et al. 2001). Our studies demonstrated that GFP label interfered with the growth characteristics of three host mutants under optimal growth conditions. Only one of the four GFPmarked strains (NS4) showed population dynamics similar to the wild-type when monitored over 10 consecutive days, even though there is high level constitutive expression of a foreign protein (GFP). Monier and Lindow (2003) observed that for $P$. syringae, the constitutively expressed GFP marker gene of strain B728a presented a lower survival rate when compared to the wild-type strain B728a on colonizing the phylloplane of bean plants. Ma et al. (2011) also demonstrated that some strains of Listeria monocytogenes, had the growth negatively affected when transformed with GFP gene. These results should likely be due to changes on the bacterial metabolic routes that produce the GFP proteins. In addition, this present work suggests that also the random integration of GFP-cassettes in each tagged-phytobacterium may be causing differential genome disturbance and interfering in the adaptive capacity of those strains. The real causes of these changes to the bacterial behavior are not clear, and should be investigated further.

All the GFP-marked strains caused a hypersensitive response on tomato leaves, characterized by necrosis resulting from localized plant cell death at the infection site (Klement 1982; Dixon and Lamb 1990). In accordance with other authors who used the hypersensitivity test as a quick method to determine the pathogenicity of bacterial strains (Klement and Goodman 1967; Kiraly et al. 1970; Atkinson et al. 1985; Goodman and Novacky 1994), our studies confirmed the pathogenicity of the GFP-marked strains using the same 
Fig. 8 Scanning

electromicrographs on abaxial tomato leaves 4 days after exposure to treatments with $B$. amyloliquefaciens, $B$. pumilus and water (control). $B$.

amyloliquefaciens aggregates at the stomatal region, ostiole (a) and between the depressions along the junctions of adjacent epithelial cells (b); B. pumilus aggregates at the stomatal region and ostiole (c), as well as between the depressions along the junctions of adjacent epithelial cells (d); $\mathbf{e}$ and $\mathbf{f}$ represent the control treatments
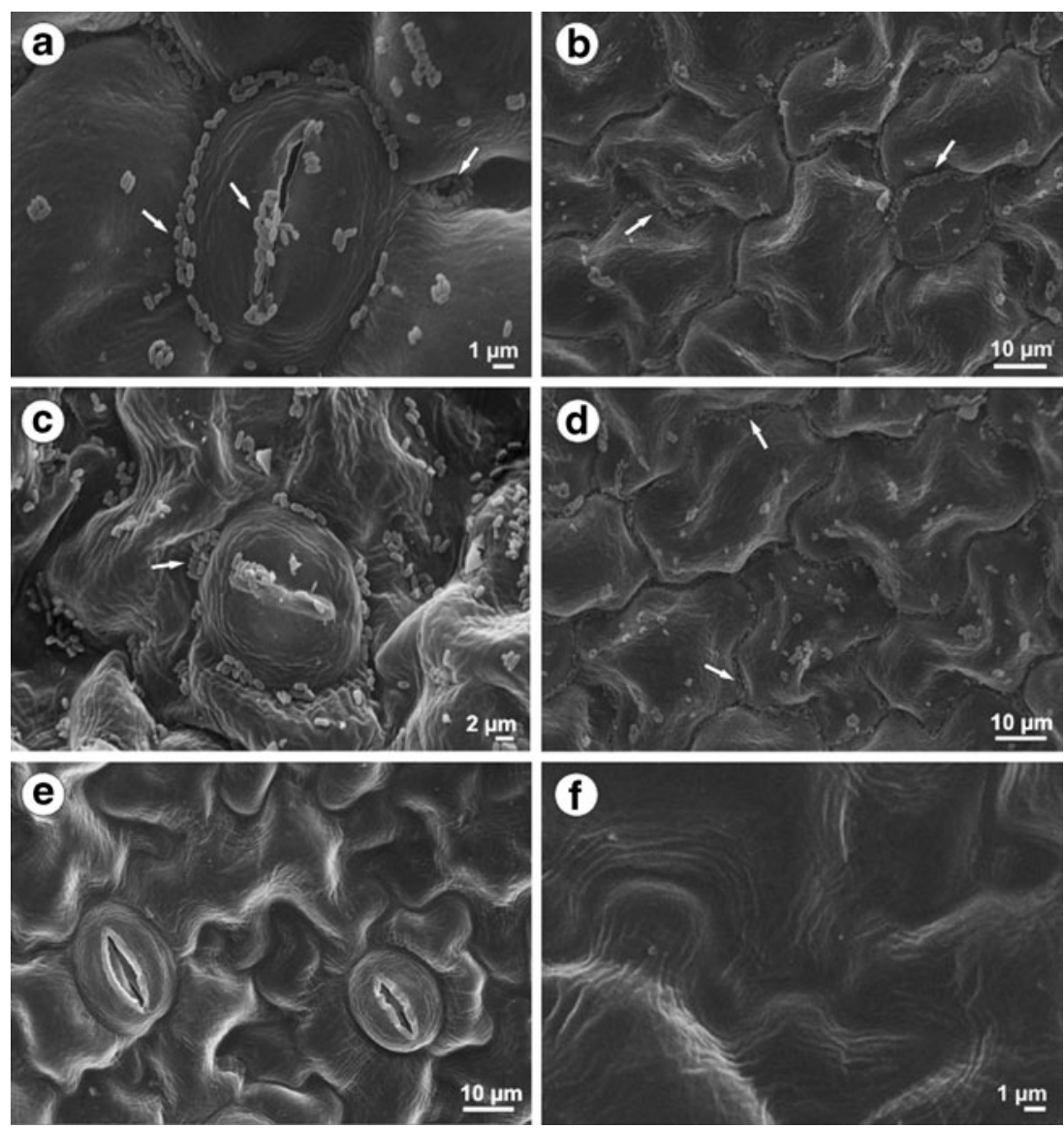

test. This suggests that the integration of GFP-cassettes in each tagged-phytobacterium does not prevent the ability of transformants to infect. Nevertheless, variation in the virulence of each GFP gene-bearing phytobacterium resulted in different disease severity levels. The difference among the disease expression of the GFP-marked strains compared to wild-type strain suggests that the random integration of GFP-cassettes interfered in regulatory activity of virulence determinants, which act co-operatively to cause disease. In studies performed by other authors with GFP-tagged plant pathogenic bacteria, virulence reduction of the strains compared to the wild-type was not observed (Newman et al. 2003; Cubero et al. 2011), although the ability to adapt to the environment was affected (Monier and Lindow 2003). Our bioassays with the GFP-marked strains showed that only strain NS4 caused similar disease expression to the wild-type strain NW making it an ideal strain to study pathogenesis of $P$. $s$. pv. tomato on tomato plants.

Biocontrol agents are known to reduce their target organism populations by a range of different mechanisms such as competition for space and nutrients, antibiosis, and induced resistance (Lindow and Brandl 2003; Monier and Lindow 2004, 2005; Lanna Filho et al. 2010). Campos Silva et al. (2008) reported the growth inhibition of $P$. $s$. pv. tomato by $B$. pumilus and $B$. amyloliquefaciens endophytic bacteria in in vitro tests.
However, the authors did not determine if the compound produced was bacteriocin, antibiotic or other antimicrobial agent. In the next step of our study we are going to identify the substance with antimicrobial activity, which may be a bacteriocin. The production of bacteriocins or bacteriocinlike substances had been described for B. coagulans, B. brevis, B. lichniformis, B. cereus, B. subtilis, B. amyloliquefaciens and other Bacillus species (Hyronimus et al. 1998; Hyung et al. 2001; Martirani et al. 2002; Risoen et al. 2004; Teo and Tan 2005; Lisboa et al. 2006). It is also known that Bacillus species synthesize large amounts of metabolites that can have both antimicrobial and induced resistance effects against other microbes (Ongena et al. 2007; Ongena and Jacques 2008). However, our study investigated competition as a mode of action and demonstrated that this can occur on the phylloplane, involving bacteria normally endophytic in nature. Similar results were demonstrated by Compant et al. (2005), where the endophytic Burkholderia sp. strain PsJN widely colonized the stomatal region and between depressions along the junctions of adjacent epithelial cells on leaves of Vitis vinifera. Therefore, endophytic bacteria appear capable of occupying niches normally occupied by phytobacteria and other pathogens, reducing the availability of nutrients necessary for the survival of these phytopathogens. Although the bacteria we investigated (B. pumilus and B. amyloliquefaciens) are endophytic in 
nature, high population levels were observed on the tomato phylloplane, 10 days following application. This suggests that these microbes are able to adapt and survive under the environmental conditions present on the phylloplane. The presence of these endophytic bacteria in large numbers on the phylloplane for such an extended period was unexpected and not previously observed in other studies on endophytic bacteria (Monier and Lindow 2004, 2005). This initial colonization may provide sufficient numbers of bacteria for subsequent colonization of the whole plant through natural openings, such as stomata and hydathodes.

This study demonstrated that a foliar application of endophytic bacterial suspension to the surface of tomato leaves reduced the severity of bacterial speck. Disease levels of plants exposed to the two antagonists were similar to that of the copper-based treatment, the chemical standard for control of plant pathogenic bacteria. We suggest that the reduction of disease severity by the antagonists was related to the occupation of niches important for survival and penetration of the phytobacteria, such as: substomatal chambers, hydathodes, trichome base and cavities between the depressions along the junctions of adjacent epithelial cells.

On the phylloplane treated with the endophytic bacteria compared to non-treated plants, we observed a low density of NS4 GFP-tagged cells, suggesting a reduction in the population associated with the presence of the endophytic bacteria. Additionally, NS4 GFP-tagged cells were not observed in the substomatal chambers (data not shown), suggesting that the endophytic bacteria may be competing for space and/or nutrients as well as synthesizing antimicrobial compounds that inhibit growth of strain NS4. Campos Silva et al. (2008) have reported that the endophytic bacteria $B$. pumilus and $B$. amyloliquefaciens can produce anti-fungal compounds active against the plant pathogenic bacterium P. s. pv. tomato, supporting our statement that antimicrobial synthesis may be a mechanism involved in the inhibition of strain NS4 growth on the phylloplane. Our studies clearly demonstrate that endophytic strains efficiently colonize the surface of tomato leaves occupying specific niches, such as: ostiole, stomatal region and cavities between the depressions along the junctions of adjacent epithelial cells, probably interfering in the colonization of P. s. pv. tomato strain NS4 (Fig. 8).

Our studies presented in this work showed the importance of the endophytic bacteria B. pumilus and B. amyloliquefaciens in the biocontrol of bacterial speck, as well as the promising use of a new GFP-marked P. s. pv. tomato strain that may be used as a model for the elucidation of phytobacteria-antagonist-host or phytobacteria-host interactions. We also reported the ability of endophytic Bacillus strains to survive under the environmental conditions present on the tomato phylloplane, increasing the knowledge known of these microorganisms in association with plant hosts. Data presented in this paper provide and important contribution to better understanding how endophytic bacteria act on tomato plants as biocontrol agents against the plant pathogenic bacterium $P$. s. pv. tomato. The next step in our research will be to develop a bio-pesticide product that consists of endophytic Bacillus strains, which will be sprayed on tomato plants in pre-and-post-planting for bacterial speck biocontrol. Our perspective is to commercialize the bioformulate as happens to the well-known Blighban A506 ${ }^{\circledR}$, Serenade ${ }^{\circledR}$ and Sonata ${ }^{\circledR}$ used for other crops.

Acknowledgments This work was supported by a grant from the Fundação de Amparo a Pesquisa do Estado de Minas Gerais (FAPEMIG) and the Conselho Nacional de Desenvolvimento Científico e Tecnológico (CNPq). We thank the Foundation for Research Assistance of São Paulo State for the fellowship to M.C.Q. (Proc.no. 2005/53748-6). We also thank the Laboratory of Electronic Microscopy and Ultrastructural analysis of the Federal University of Lavras for providing the Scanning Electron Microscope and other facilities.

\section{References}

Allison DG, Sattenstall MA (2007) The influence of green fluorescent protein incorporation on bacterial physiology: a note of caution. $\mathrm{J}$ Appl Microbiol 103:318-324

Atkinson MM, Huang JS, Knoppw JA (1985) The hypersensitive reaction of tobacco to Pseudomonas syringae pv. pisi. Plant Physiol 79:843-847

Bloemberg GV, O’Toole GA, Lugtenberg BJJ, Kolter R (1997) Green fluorescent protein as marker for Pseudomonas spp. Appl Environ Microbiol 63:4543-4551

Campos Silva JR, Souza RM, Zacarone AB, Silva LHCP, Castro AMS (2008) Bactérias endofíticas no controle e inibição in vitro de Pseudomonas syringae pv. tomato, agente da pinta bacteriana do tomateiro. Cien Agrotec 32:1062-1072

Compant S, Reiter B, Sessitsch A, Nowak J, Clément C, Barka EA (2005) Endophytic colonization of Vitis vinifera L. by plant growth-promoting bacterium Burkholderia sp. strain PsJN. Appl Environ Microbiol 71:1685-1693

Cubero J, Gell I, Johnson EG, Redondo A, Graham JH (2011) Unstable green fluorescent protein for study of Xanthomonas citri subsp. citri survival on citrus. Plant Pathol 60:977-985

Dandie CE, Thomas SM, McClure NC (2001) Comparison of a range of green fluorescent protein-tagging vectors for monitoring a microbial inoculant in soil. Lett Appl Microbiol 32:26-30

Dixon RA, Lamb CJ (1990) Molecular communication in interactions between plants and microbial pathogens. Annu Rev Plant Physiol Plant Mol Biol 41:339-367

Ferreira A, Quecine MC, Lacava PT, Oda S, Azevedo JL, Araújo WL (2008) Diversity of endophytic bacteria from Eucalyptus species seeds and colonization of seedlings by Pantoea agglomerans. FEMS Microbiol Lett 287:8-14

Gerhardt PE (1994) Methods for general and molecular bacteriology. American Society for Microbiology, Washington

Goodman RN, Novacky AJ (1994) The hypersensitive reaction in plants to pathogens. APS Press, Saint Paul

Halfeld-Vieira BA, Vieira JR, Romeiro RS, Silva HSA, BaracatPereira MC (2006) Induction of systemic resistance in tomato by the autochthonous phylloplane resident Bacillus cereus. Pesq Agrop Brasileira 41:1247-1252

Hirano SS, Upper CD (2000) Bacteria in the leaf ecosystem with emphasis on Pseudomonas syringae: a pathogen, ice nucleus, and epiphyte. Microbiol Mol Biol Rev 64:624-653 
Hyronimus B, Le Marrec C, Urdaci MC (1998) Coagulin, a bacteriocin-like inhibitory substance produced by Bacillus coagulans I4. J Appl Microbiol 85:42-50

Hyung JM, Kwang-Soo K, Jong-Hyun P, Myung-Woo B, Young-Bae K, Han-Joon H (2001) Bacteriocin with a broad antimicrobial spectrum, produced by Bacillus sp. isolated from Kimchi. J Microbiol Biotechnol 11:577-584

Jardine DJ, Stephens CT (1987) Influence of timing of application and chemical on control of bacterial speck of tomato. Plant Dis 71:405-408

Jones JB, Jones JP, Stall RE, Zitter TA (1991) Compendium of tomato diseases. APS press, Sant Paul

Kado CI, Heskett MG (1970) Selective media for isolation of Agrobacterium, Corynebacterium, Erwinia, Pseudomonas and Xanthomonas. Phytopathology 60:969-979

Kiraly Z, Klement Z, Solimosy F, Voros J (1970) Methods in plant pathology. Akademiai Kiadó, Budapest

Klement Z, Goodman RN (1967) The hypersensitive reaction to infection by bacterial plant pathogens. Annu Rev Plant Phytopathol 5:17-44

Klement Z (1982) Hypersensitivity. In: Mount MS, Lacy GH (eds) Phytopathogenic Prokaryotes, 2nd edn. Academic Press, New York, pp 149-177

Lanna Filho R, Romeiro RS, Alves E (2010) Bacterial spot and early blight biocontrol by epiphytic bacteria in tomato plants. Pesq Agrop Brasileira 45:1381-1387

Lindow SE, Brandl MT (2003) Microbiology of the phyllosphere. Appl Environ Microbiol 69:1875-1883

Lisboa MP, Bonatto D, Bizani D, Henriques JAP, Brandelli A (2006) Characterization of a bacteriocin-like substance produced by Bacillus amyloliquefaciens isolated from the Brazilian Atlantic forest. J Int Microbiol 9:111-118

Ma L, Zhang G, Doyle MP (2011) Green fluorescent protein labeling of Listeria, Salmonella, and Escherichia coli O157:H7 for safetyrelated studies. PLoS One 6:1-7

Martirani L, Varcamonti M, Naclerio G, De Felice M (2002) Purification and partial characterization of bacillocin 490, a novel bacteriocin produced by a thermophilic strain of Bacillus licheniformis. Microb Cell Factories 1:1-5

Melotto M, Underwood W, Koczan J, Nomura K, He SY (2006) Plant stomata function in innate immunity against bacterial invasion. Cell 126:969-980

Monier JM, Lindow SE (2003) Pseudomonas syringae responds to the environment on leaves by cell size reduction. Phytopathology 93:1209-1216

Monier JM, Lindow SE (2004) Frequency, size, and localization of bacterial aggregates on bean leaf surfaces. Appl Environ Microbiol 70:346-355
Monier JM, Lindow SE (2005) Aggregates of resident bacteria facilitate survival of immigrant bacteria on leaf surfaces. Microb Ecol 49:343-352

Newman KL, Almeida RPP, Purcell AH, Lindow SE (2003) Use of a green fluorescent strain for analysis of Xylella fastidiosa colonization of Vitis vinifera. Appl Environ Microbiol 69:7319-7327

Ongena M, Jacques P (2008) Bacillus lipopeptides: versatile weapons for plant disease biocontrol. Trends Microbiol 16:115-125

Ongena M, Jourdan E, Adam A, Paquot M, Brans A, Joris B, Arpigny JL, Thonart P (2007) Surfactin and fengycin lipopeptides of Bacillus subtilis as elicitors of induced systemic resistance in plants. Environ Microbiol 9:1084-1090

Priest FG, Goodfellow M, Shute LA, Berkeley RCW (1987) Bacillus amyloliquefaciens sp. nov., nom. rev. Int J Syst Bacteriol 37:6971

Risoen PA, Ronning P, Hegna IK, Kolsto AB (2004) Characterization of a broad range antimicrobial substance from Bacillus cereus. J Appl Microbiol 96:648-655

Saad AT, Hassan HA (2000) Pathogenesis and control of bacterial speck, Pseudomonas syringae pv. tomato, on tomato. EPPO Bull 30:341-345

Sambrook J, Fritsch EF, Maniatis T (1989) Molecular cloning: a laboratory manual, 2nd edn. Cold Spring Harbor Laboratory Press, New York

Shen HAO, Keen NT (1993) Characterization of the promoter of avirulence gene D from Pseudomonas syringae pv. tomato. J Bacteriol 175:5916-5924

Silva HSA, Romeiro RS, Macagnan D, Halfeld-Vieira BA, Baracat-Pereira MC, Mounteer A (2004) Rhizobacterial induction of systemic resistance in tomato plants: non-specific protection and increase in enzyme activities. Biol Control 29:288-295

Skillman LC, Southerland IW, Jones MV, Goulsbra A (1998) Green fluorescent protein as a novel species-specific marker in enteric dual-species biofilms. Microbiol 144:2095-2101

Statsoft (2005) Statistica for Windows: user's manual. Tulsa Oklahoma: Statsoft Incorporation. http://www.statsoft.com. Accessed 23 June 2011

Teo AYL, Tan HM (2005) Inhibition of Clostridium perfringens by a novel strain of Bacillus subtilis isolated from the gastrointestinal tracts of healthy chickens. Appl Environ Microbiol 71:41854190

Yunis H, Bashan Y, Okon Y, Henis Y (1980) Weather dependence yield losses and control of bacterial speck of tomato caused by Pseudomonas syringae pv. tomato. Plant Dis 64:937-939 